\title{
CTRB1 Gene
}

National Cancer Institute

\section{Source}

National Cancer Institute. CTRB1 Gene. NCI Thesaurus. Code C118241.

This gene plays a role in gastrointestinal proteolysis. 